\title{
Endotracheal suction in intubated critically ill adult patients undergoing mechanical ventilation: a systematic review ${ }^{1}$
}

\author{
Débora Oliveira Favretto ${ }^{2}$ \\ Renata Cristina de Campos Pereira Silveira ${ }^{3}$ \\ Silvia Rita Marin da Silva Canini ${ }^{3}$ \\ Livia Maria Garbin ${ }^{4}$ \\ Fernanda Titareli Merízio Martins ${ }^{5}$ \\ Maria Célia Barcellos Dalri ${ }^{3}$
}

\begin{abstract}
Aim: identify and analyze in the literature the evidence of randomized controlled trials on care related to the suctioning of endotracheal secretions in intubated, critically ill adult patients undergoing mechanical ventilation. Method: the search was conducted in the PubMed, EMBASE, CENTRAL, CINAHL and LILACS databases. From the 631 citations found, 17 studies were selected. Results: Evidence was identified for six categories of intervention related to endotracheal suctioning, which were analyzed according to outcomes related to hemodynamic and blood gas alterations, microbial colonization, nosocomial infection, and others. Conclusions: although the evidence obtained is relevant to the practice of endotracheal aspiration, the risks of bias found in the studies selected compromise the evidence's reliability.
\end{abstract}

Descriptors: Nursing Care; Critical Care; Suction; Intubation, Intratracheal; Intensive Care Units.

\footnotetext{
${ }^{1}$ Paper extracted from Master's Dissertation "Aspiração endotraqueal em pacientes críticos adultos intubados sob ventilação mecânica: revisão sistemática", presented to Escola de Enfermagem de Ribeirão Preto, Universidade de São Paulo, WHO Collaborating Centre for Nursing Research Development, Brazil. Supported by Fundação de Amparo à Pesquisa do Estado de São Paulo (FAPESP), Process \# 2009/06693-2.

2 MSc, Assistant Professor, Nursing undergraduate course, Instituto de Ciências Exatas e Naturais, Universidade Federal de Mato Grosso, Campus Universitário de Rondonópolis, Brazil.

${ }^{3}$ PhD, Professor, Escola de Enfermagem de Ribeirão Preto, Universidade de São Paulo, WHO Collaborating Centre for Nursing Research Development, Brazil.

${ }^{4}$ RN, MSc, Escola de Enfermagem de Ribeirão Preto, Universidade de São Paulo, WHO Collaborating Centre for Nursing Research Development, Brazil.

${ }^{5}$ RN, PhD, Escola de Enfermagem de Ribeirão Preto, Universidade de São Paulo, WHO Collaborating Centre for Nursing Research Development, Brazil.
} 


\section{Aspiração endotraqueal em pacientes adultos com via aérea artificial: revisão sistemática}

Objetivo: identificar e analisar evidências oriundas de ensaios clínicos controlados e randomizados sobre os cuidados relacionados à aspiração de secreções endotraqueais em pacientes adultos, em estado crítico, intubados e sob ventilação mecânica. Método: a busca foi realizada nas bases de dados Pubmed, Embase, Central, Cinahl e Lilacs. Das 631 referências encontradas, 17 estudos foram selecionados. Resultados: identificaram-se evidências quanto a seis categorias de intervenções relacionadas à aspiração endotraqueal, as quais foram analisadas segundo desfechos referentes a alterações hemodinâmicas e dos gases sanguíneos, colonização microbiana, infecção nosocomial, dentre outros. Resultados: as evidências obtidas são relevantes para a prática da aspiração endotraqueal, entretanto, os riscos de viés dos estudos selecionados comprometem a sua confiabilidade.

Descritores: Cuidados de Enfermagem; Cuidados Críticos; Sucção; Intubação Intratraqueal; Unidades de Terapia Intensiva.

\section{Aspiración endotraqueal en pacientes adultos con veía aérea artificial: revisión sistemática}

Objetivo: identificar y analizar evidencias oriundas de ensayos clínicos controlados y hechos aleatorios sobre las atenciones relacionados a la aspiración de secreciones endotraqueales en pacientes adultos, en estado crítico, intubados y bajo ventilación mecánica. Método: la busca fue realizada en las bases de datos PUBMED, EMBASE, CENTRAL, CINAHL y LILACS. De las 631 referencias encontradas, 17 estudios fueron seleccionados. Resultados: se identificaron evidencias en cuanto a seis categorías de intervenciones relacionadas a la aspiración endotraqueal, las cuales fueron analizadas según los resultados referentes a alteraciones hemodinámicas y de los gases sanguíneos, colonización microbiana, infección nosocomial, entre otros. Resultados: las evidencias logradas son relevantes para la práctica de la aspiración endotraqueal, mientras, los riesgos de bies de los estudios seleccionados comprometen su confiabilidad.

Descriptores: Atención de Enfermería; Cuidados Críticos; Succión; Intubación Intratraqueal; Unidades de Terapia Intensiva.

\section{Introduction}

Endotracheal suction is a procedure which aims to keep airways patent by mechanically removing accumulated pulmonary secretions, above all in patients with artificial airways ${ }^{(1)}$.

Despite being a necessary procedure, it can lead to complications, such as lesions in the tracheal mucosa, pain, discomfort, infection, alterations of the hemodynamic parameters and of the arterial gases, bronchoconstriction, atelectasis, increase in intra-cranial pressure, and alterations in cerebral blood flow, among others $^{(1-2)}$.
Considering this procedure's complexity, a prior evaluation of the need for suction is indispensable, as this is an invasive, complex procedure that must be undertaken by judicious indication, as it can cause harm to the patient ${ }^{(1,3)}$. For this procedure, it is important that the nurse has knowledge based on valid scientific evidence concerning the different methods of endotracheal suction and aspects related to it.

Despite there being scientific evidence for the safe and efficient accomplishment of endotracheal suction, many of these recommendations have not been 
observed in nurses' clinical practice, due above all to poor knowledge about this procedure ${ }^{(4)}$. It is believed that grouping and synthesizing the available evidence can assist clinical nurses, nurse lecturers and student nurses in incorporating it into their care practice, as well as guiding new research.

It was in this context that the present study aimed to identify and analyze the scientific evidence about nursing care related to the suctioning of endotracheal secretions in critically-ill, intubated adult patients undergoing mechanical ventilation.

\section{Methods}

This is a systematic review of the literature, guided by the recommendations of the Cochrane Collaboration ${ }^{(5)}$.

The review question, devised based in the PICO strategy ${ }^{(6)}$, was: considering the different methods and steps of endotracheal suction, what is the most effective and safest way of accomplishing it in criticallyill, intubated adult patients, undergoing mechanical ventilation, so as to keep the airways unobstructed, while avoiding or minimizing its complications?

The inclusion criteria were studies of randomized controlled trials (RCT), published in full, in English, Portuguese or Spanish, undertaken with adult patients ( $\geq 18$ years old), who were critically ill, intubated and undergoing mechanical ventilation, and which addressed the effectiveness and safety of endotracheal suction.

The search was carried out in the databases PubMed, EMBASE, CENTRAL, CINAHL and LILACS. The search strategy considered sets of terms related to the study population $(P)$; to the intervention evaluated (I); to the type of study to be included (type of study) and to the exclusion of pediatric and neonatal studies (limits). Descriptors were selected from each database's controlled vocabulary, as well as non-controlled descriptors, which were combined within each set of terms using the Boolean connector OR. The search strategy proposed by the Cochrane Collaboration ${ }^{(5)}$ was adapted for finding the ECCRs (Figure 1).

\begin{tabular}{|c|c|c|}
\hline & & PUBMED \\
\hline & MESH & Critical care; Critical illness; Intensive care; Intensive Care Units; Intubation, intratracheal; Respiration, Artificial \\
\hline$r$ & NCD & Endotracheal intubation; Mechanical ventilation \\
\hline & MESH & Suction \\
\hline 1 & NCD & Endotracheal suction; Endotracheal suctioning; Aspiration, Mechanical; Tracheal suction; Tracheal suctioning \\
\hline & dy design & $\begin{array}{l}\text { ("randomized controlled trial"[Publication Type] OR "controlled clinical trial"[Publication Type] OR "random"[Title/Abstract] OR } \\
\text { "randomly"[Title/Abstract] OR "randomize"[Title/Abstract] OR "randomized"[Title/Abstract] OR "randomization"[Title/Abstract] } \\
\text { OR "randomise"[Title/Abstract] OR "randomised"[Title/Abstract] OR "randomisation"[Title/Abstract] OR "placebo"[Title/Abstract] } \\
\text { OR trial[Title] OR "Clinical Trials as Topic"[Mesh:NoExp] OR "Random Allocation"[Mesh] OR "Randomized Controlled Trials as } \\
\text { Topic"[Mesh] OR "Single-Blind Method"[Mesh] OR "Double-Blind Method"[Mesh]) NOT ("Animals"[Mesh] NOT "Humans"[Mesh]) }\end{array}$ \\
\hline & & $\begin{array}{l}\text { Infant, Newborn; Infant, Premature; Infant; Child, Preschool; Child; Pediatrics; Pediatric Nursing; Intensive Care Units, Pediatric; } \\
\text { Neonatology; Neonatal Nursing; Intensive Care, Neonatal; Intensive Care Units, Neonatal; Adolescent }\end{array}$ \\
\hline & & EMBASE \\
\hline & EMTREE & Intensive care; Critical illness; Intensive care nursing; Intensive Care Unit; Endotracheal intubation; Intubation; Artificial ventilation \\
\hline$r$ & NCD & Mechanical ventilation \\
\hline 1 & EMTREE & Suction; Tracheobronchial toilet; Tracheal aspiration procedure \\
\hline 1 & NCD & Endotracheal suction; Endotracheal suctioning; Mechanical aspiration \\
\hline & dy design & $\begin{array}{l}\text { random:ab,ti OR randomly:ab,ti OR randomize:ab,ti OR randomized:ab,ti OR randomization:ab,ti OR randomization:ab,ti OR } \\
\text { randomised:ab,ti OR randomisation:ab,ti OR trial:ti OR placebo:ab,ti OR 'randomized controlled trial'/de OR 'controlled clinical } \\
\text { trial'/de OR 'clinical trial'/de OR 'controlled study'/de OR 'intervention study'/de OR 'randomization'/de OR 'single blind procedure'/ } \\
\text { de OR 'double blind procedure'/de }\end{array}$ \\
\hline & & $\begin{array}{l}\text { Newborn; infant; prematurity; preschool child; child; pediatrics; pediatric nursing; pediatric intensive care nursing; neonatology; } \\
\text { newborn nursing; newborn intensive care; newborn intensive care nursing; adolescence; adolescent }\end{array}$ \\
\hline & & CENTRAL \\
\hline & $\begin{array}{l}\text { ing into a } \\
\text { l limits. }\end{array}$ & that this base recruits controlled trials from PUBMED and EMBASE, the same descriptors were adopted for these bases for P, I \\
\hline & & CINAHL \\
\hline $\mathrm{P}$ & Titles & $\begin{array}{l}\text { Critical Care Nursing; Critical Care; Critical Illness; Intensive Care Units; Intubation; Intubation, Intratracheal; Respiration, Artificial; } \\
\text { Ventilators, Mechanical }\end{array}$ \\
\hline & NCD & Endotracheal intubation \\
\hline 1 & Titles & Suction; Suctioning, Endotracheal \\
\hline 1 & NCD & Endotracheal suction \\
\hline & dy design & $\begin{array}{l}\text { (PT "controlled clinical trial") or (PT "randomized controlled trial") or (TI "random") or (AB "random") or (TI "randomly") or (AB } \\
\text { "randomly") or (TI "randomize") or (AB "randomize") or (TI "randomized") or (AB "randomized") or (TI "randomization") or (AB } \\
\text { "randomization") or (TI "randomise") or (AB "randomise") or (TI "randomised") or (AB "randomised") or (TI "randomisation") or (AB } \\
\text { "randomisation") or (TI "placebo") or (AB "placebo") or (TI "trial") or (MH "clinical trials") or (MH "random sample") or (MH "random } \\
\text { assignment") or (MH "single-blind studies") or (MH "double-blind studies") }\end{array}$ \\
\hline
\end{tabular}

(The Figure 1 continue in the next page...) 


\begin{tabular}{|c|c|c|}
\hline \multicolumn{2}{|c|}{ Limits } & $\begin{array}{l}\text { Infant; Infant, Newborn; Infant, Premature; Child; Child, Preschool; Pediatrics; Intensive Care Units, Pediatric; Pediatric Critical } \\
\text { Care Nursing; Pediatric Care; Pediatric Nursing; Neonatology; Intensive Care Units, Neonatal; Intensive Care, Neonatal; Neonatal } \\
\text { Intensive Care Nursing; Neonatal Nursing; Adolescence }\end{array}$ \\
\hline \multicolumn{3}{|r|}{ LILACS } \\
\hline$P$ & DECS & $\begin{array}{l}\text { cuidados críticos; cuidados intensivos; unidades de terapia intensiva; intubacao intratraqueal; intubacao endotraqueal; respiracao } \\
\text { artificial; respiradores mecânicos; ventilacao mecânica }\end{array}$ \\
\hline I & DECS & Sucção; aspiracao mecânica \\
\hline
\end{tabular}

$\mathrm{P}=$ Patient; $\mathrm{I}$ = intervention; MESH = Controlled vocabulary in PUBMED database; NCD = Non-controlled descriptors; EMTREE = Controlled vocabulary from the EMBASE database; Titles = Controlled vocabulary from the CINAHL database; DECS = Controlled vocabulary from the LILACS database.

Figure 1 - Controlled and non-controlled descriptors used in the search strategy for population, intervention, study design and limits, according to database. Ribeirão Preto, São Paulo, Brazil, 2012

The search strategy for the databases PubMed, EMBASE and CINAHL was: ((P AND I) AND study design) NOT limits. For the CENTRAL database, which is specific for controlled trials, the strategy adopted was: (P AND I) NOT limits. For the LILACS database, on the other hand, the search strategy which permitted the identification of the most studies was: P AND I. The search was undertaken in April 2010; 631 citations were found.
The selection of the studies (Figure 2) was initially carried out based on a reading of the titles and abstracts, based on the inclusion criteria. 36 publications were considered potentially eligible: 35 contained insufficient information for selection in the titles and abstracts. These 71 studies were selected for reading in full, of which 17 were included in this systematic review's sample.

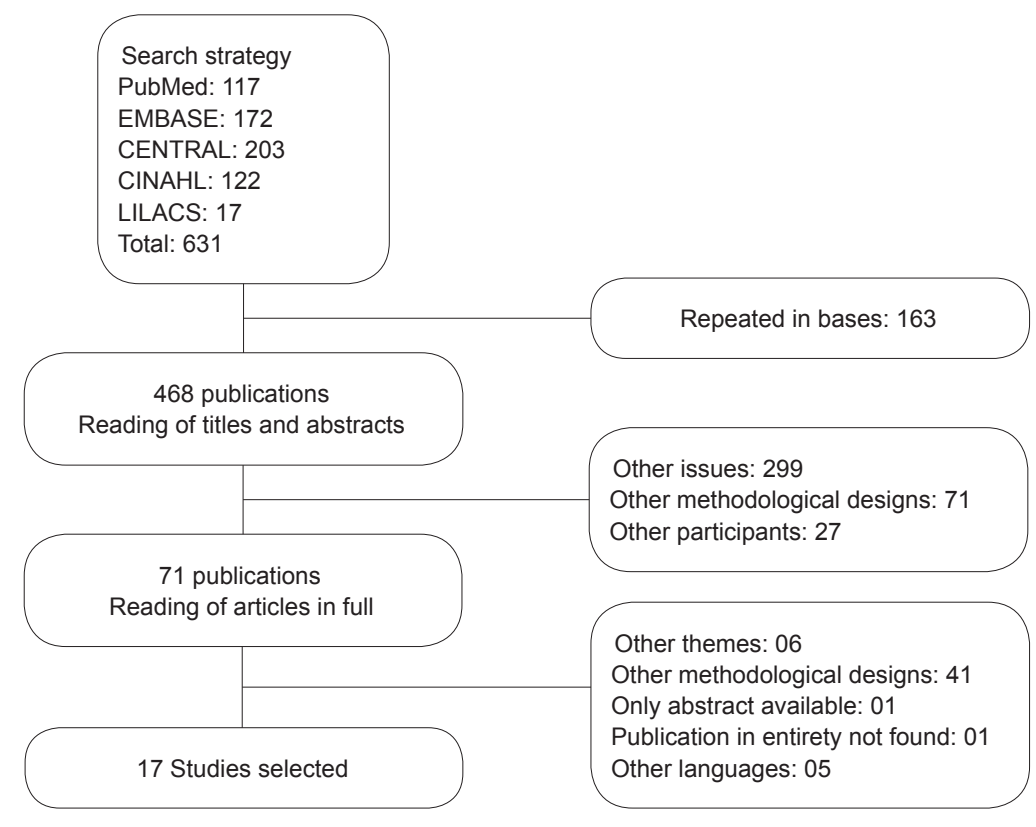

Figure 2 - Flowchart of the selection of the studies found. Ribeirão Preto, São Paulo, Brazil, 2012

A data collection form devised for the present study was used for the extraction of the data. It took into consideration the instructions on content and appearance presented by the Cochrane Collaboration ${ }^{(5)}$.

The extraction of the data from each study was undertaken by two reviewers. Initially, the principal reviewer extracted the data from all of the studies selected. Next, the studies were distributed among three reviewers, who acted as independent validators. The studies were also evaluated for risk of bias, taking into account the sequence generation, allocation concealment, blinding of participants, care providers and the evaluators of the outcomes, incomplete data on outcomes, selective reporting and other sources of bias $^{(5,7)}$. It is considered that studies with a low risk of bias are unlikely to have serious alterations in their 
results. An uncertain level of risk, on the other hand, raises doubts about the reliability of the studies' results, and a high risk of bias seriously weakens the results' reliability ${ }^{(7)}$.

Finally, the data extracted from the studies included in this systematic review was analyzed and presented in a descriptive form.

\section{Results}

The 17 RCT included were published between 1987 and 2009, with 11 (64.7\%) published after 2000, 2003 standing out, with four articles (23.5\%).

The results of the studies allowed the grouping of evidence into six categories of intervention related to endotracheal suction: research-based endotracheal suction compared to normal endotracheal suction, in one study ${ }^{(8)}$; routine endotracheal suction compared to minimally-invasive endotracheal suction, in two studies $^{(9-10)}$; open system endotracheal suctioning compared to closed system endotracheal suctioning, in eight studies(11-18); change of closed system at 24 compared to 48 hours, in two studies ${ }^{(19-20)}$; daily change of the closed system compared to non-routine change, in one study(21); and saline instillation compared to nonsaline instillation, in three studies ${ }^{(22-24)}$.

The interventions were undertaken analyzing outcomes referent to hemodynamic alterations, alterations in blood gases, microbial colonization and nosocomial infection, quantity of secretion suctioned, pulmonary alterations, memory of the experience of endotracheal suction on the part of the patient, and discomfort related to the suction.

The results of the outcomes analyzed for the intervention categories in the studies selected are presented in Figure 3.

\begin{tabular}{|c|c|}
\hline \multicolumn{2}{|r|}{ Authors: Celik, Elbas(8) } \\
\hline \multicolumn{2}{|c|}{$\begin{array}{l}\text { Groups studied } \\
\text { Group } 1(n=38) \text { : Research-based endotracheal suction } \\
\text { Group } 2(n=42) \text { : Normal endotracheal suction }\end{array}$} \\
\hline Outcome & Result \\
\hline $\mathrm{CF}$ & $\begin{array}{l}\text { Group } 1: 1 \text { min before the procedure, } 20 \text { patients had normal values and } 18 \text { had abnormal values; } 15 \text { min after the } \\
\text { procedure, } 36 \text { had normal values and } 2 \text { had abnormal values }(p<0.05) \text {. Group } 2: \text { no statistical difference between the } \\
\text { points in which the outcome was measured }(p>0.05) \text {. There was a statistically-significant difference between the groups } \\
\text { only in the } 15 \text { min after the procedure }(p<0.05) \text {. }\end{array}$ \\
\hline MAP & $\begin{array}{l}\text { Group } 1: 1 \mathrm{~min} \text { before the procedure, } 20 \text { patients had normal values and } 18 \text { had abnormal values; } 15 \text { min after the } \\
\text { procedure, } 34 \text { had normal values and } 4 \text { had abnormal values }(p<0.05) \text {. Group } 2: \text { no statistical difference between the } \\
\text { points in which the outcome was measured }(p>0.05) \text {. There was a statistically-significant difference between the groups } \\
\text { only in the } 15 \text { min after the procedure }(p<0.05) \text {. }\end{array}$ \\
\hline $\mathrm{SatO}_{2}$ & No statistical difference between the points in which the outcome was measured for both groups $(p>0.05)$. \\
\hline $\mathrm{PaO}_{2}$ & $\begin{array}{l}\text { Group 1: } 1 \text { min before the procedure, } 5 \text { patients had normal values and } 33 \text { had abnormal values; } 15 \text { min after the } \\
\text { procedure, } 16 \text { had normal values and } 22 \text { had abnormal values }(p<0.05) \text {. Group } 2: \text { no statistical difference between the } \\
\text { points in which the outcome was measured }(p>0.05) \text {. There was a statistically-significant difference between the groups } \\
\text { only in the } 15 \text { min after the procedure }(p<0.05) \text {. }\end{array}$ \\
\hline $\mathrm{PaCO}_{2}$ & $\begin{array}{l}\text { Group 1: } 1 \text { min before the procedure, } 12 \text { patients had normal values and } 26 \text { had abnormal values; } 15 \text { min after the } \\
\text { procedure, } 33 \text { had normal values and } 5 \text { had abnormal values }(p<0.05) \text {. Group } 2 \text { : there was no statistical difference } \\
\text { between the moments in which the outcome was measured }(p>0.05) \text {. There was a statistically-significant difference } \\
\text { between the groups only in the } 15 \text { min after the procedure }(p<0.05) \text {. }\end{array}$ \\
\hline \multicolumn{2}{|r|}{ Authors: Leur et al.(9) } \\
\hline \multicolumn{2}{|c|}{$\begin{array}{l}\text { Groups studied } \\
\text { Group } 1(n=197) \text { : Routine endotracheal suctioning } \\
\text { Group } 2(n=186) \text { : Minimally-invasive endotracheal suctioning }\end{array}$} \\
\hline Outcome & Result \\
\hline $\mathrm{CF}$ & Group 1: $0.1 \%$ of bradycardia. Group 2: $0.05 \%(p=0.24)$ \\
\hline AP & Group 1: $24.5 \%$ with high AP. Group 2: $16.8 \%(p<0.001)$ \\
\hline PP & Group 1: $1.4 \%$ with high PP. Group 2: $0.9 \%(p=0.007)$ \\
\hline Cardiac rhythm & Group 1: $6.6 \%$ with arrhythmia. Group 2: $7.9 \%(p=0.002)$ \\
\hline $\mathrm{SatO}_{2}$ & Group 1: $2.7 \%$ with fall in $\mathrm{SatO}_{2}$. Group 2: $2.0 \%(p=0.01)$ \\
\hline Blood in mucus & Group 1: $3.3 \%$. Group 2: $0.9 \%(p<0.001)$ \\
\hline Pulmonary infection & Group 1: $14.2 \%$. Group 2: $12.9 \%(p=0.708)$ \\
\hline \multicolumn{2}{|r|}{ Authors: Leur et al. ${ }^{(10)}$} \\
\hline \multicolumn{2}{|c|}{$\begin{array}{l}\text { Groups studied } \\
\text { Group } 1(n=113) \text { : Routine endotracheal suctioning } \\
\text { Group } 2 \text { (95): Minimally-invasive endotracheal suctioning }\end{array}$} \\
\hline Outcome & Result \\
\hline
\end{tabular}




\begin{tabular}{|c|c|}
\hline CF & Group 1: $0.1 \%$ of bradycardia. Group 2: $0.0 \%(p=0.068)$ \\
\hline AP & Group 1: $16.3 \%$ with high AP. Group 2: $13.7 \%(p=0.003)$ \\
\hline PP & Group 1: $1.6 \%$ with high PP. Group 2: $1.0 \%(p=0.053)$ \\
\hline Cardiac rhythm & Group 1: $4.6 \%$ with arrhythmia. Group 2: $5.6 \%(p=0.002)$ \\
\hline $\mathrm{SatO}_{2}$ & Group 1: $2.6 \%$ with a drop in $\mathrm{SatO}_{2}$. Group 2: $1.4 \%(p=0.001)$ \\
\hline $\begin{array}{l}\text { Discomfort during } \\
\text { suctioning }\end{array}$ & Group 1: average of $5.9 \mathrm{~cm}$. Group 2: $5 \mathrm{~cm}(p=0.136)$ \\
\hline $\begin{array}{l}\text { Memory of being } \\
\text { suctioned }\end{array}$ & $\begin{array}{l}\text { Group 1: } 40.7 \% \text {. Group 2: } 20 \%(p=0.001) \\
\text { Group } 1 \text { has a risk } 2.76 \text { times greater than group } 2 \text { of remembering being suctioned. }\end{array}$ \\
\hline & Authors: Adams et al. ${ }^{(11)}$ \\
\hline \multicolumn{2}{|c|}{$\begin{array}{l}\text { Groups studied } \\
\text { Group } 1(n=10): \text { Open system } \\
\text { Group } 2(n=10): \text { Closed system }\end{array}$} \\
\hline Outcome & Result \\
\hline VAP & None of the patients studied was diagnosed with VAP. \\
\hline Microbial colonization & Group 1: 05 patients diagnosed (50\%). Group 2: 05 (50\%). \\
\hline & Authors: Combes et al..$^{(12)}$ \\
\hline \multicolumn{2}{|c|}{ Groups studied: Group $1(n=50)$ : Open system; Group $2(n=54)$ : Closed system } \\
\hline Outcome & Result \\
\hline VAP & $\begin{array}{l}\text { Group 1: } 09 \text { patients diagnosed (18\%). Group 2: } 04(7.4 \%) \text {. No significant difference with univariate analysis }(p=0.07) \text {. } \\
\text { According to the Cox model the relative risk indicated a risk } 3.4 \text { times greater of VAP occurring in Group } 1(p=0,05)\end{array}$ \\
\hline \multicolumn{2}{|r|}{ Authors: Johnson et al. ${ }^{(13)}$} \\
\hline \multicolumn{2}{|c|}{ Groups studied: Group $1(n=19)$ : Open system; Group $2(n=16):$ Closed system } \\
\hline Outcome & Result \\
\hline CF & $\begin{array}{l}\text { After aspiration, both groups presented higher values compared to the baseline (before aspiration). Only } 30 \text { min after } \\
\text { aspiration was there a significant difference between the groups }(p=0.02) \text {. }\end{array}$ \\
\hline AP & $\begin{array}{l}\text { After aspiration, both the groups presented high values compared to the baseline. There was a significant difference } \\
\text { between the groups at all points observed }(p<0.05) \text {. }\end{array}$ \\
\hline $\mathrm{SatO}_{2}$ & $\begin{array}{l}\text { There was a significant difference between the groups at all points observed }(p<0.05) \text {. The open system presented a fall } \\
\text { in values and the closed system presented an increase, relative to the baseline. }\end{array}$ \\
\hline Cardiac rhythm & $\begin{array}{l}\text { Arrhythmias were observed in both groups, principally after the aspiration. Group 1: } 18 \text { arrhythmias. Group } 2: 3 . \\
p=0.0001 .\end{array}$ \\
\hline VAP & Group 1: $10(52.63 \%)$. Group 2: $8(50 \%)$. The $p$ value was not presented. \\
\hline \multicolumn{2}{|r|}{ Authors: Lorente et al..$^{(14)}$} \\
\hline \multicolumn{2}{|c|}{ Groups studied: Group $1(n=221)$ : Open system; Group $2(n=236)$ : Closed system } \\
\hline Outcome & Result \\
\hline VAP & Group 1: 31 (14.1\%). Group 2: 33 (13.9\%). p=0.99 \\
\hline \multicolumn{2}{|r|}{ Authors: Lorente et al..$^{(15)}$} \\
\hline \multicolumn{2}{|c|}{ Groups studied: Group $1(n=233)$ : Open system; Group 2: $(n=210)$ Closed system: } \\
\hline Outcome & Result \\
\hline VAP & Group 1: 42 (18.02\%). Group 2: $23(20.47 \%) . p=0.62$ \\
\hline \multicolumn{2}{|r|}{ Authors: Rabitsch et al..$^{(16)}$} \\
\hline \multicolumn{2}{|c|}{ Groups studied: Group 1 ( $n=12)$ : Open system; Group $2(n=12)$ : Closed system } \\
\hline Outcome & Result \\
\hline $\mathrm{SatO}_{2}$ & $\begin{array}{l}\text { Before aspiration, there was no statistical difference between the groups }(p>0.05) \text {. Immediately following aspiration, there } \\
\text { was a significant fall ( } p<0.0001) \text { in Group 1, while the values in Group } 2 \text { remained the same. The values in Group } 1 \text { were } \\
\text { statistically lower than in Group } 2(p<0.0001) \text {. }\end{array}$ \\
\hline VAP & Group 1: 5 (41.66\%). Group 2: none. $p=0.037$ \\
\hline Cross-contamination & Group 1: 5 (41.66\%). Group 2: none. $p=0.037$ \\
\hline \multicolumn{2}{|r|}{ Authors: Topeli et al. ${ }^{(17)}$} \\
\hline \multicolumn{2}{|c|}{ Groups studied: Group $1(n=37)$ : Open system; Group $2(n=41)$ : Closed system } \\
\hline Outcome & Result \\
\hline VAP & Group 1: 9 (24,3\%). Group 2: $13(31,7 \%) . p=0,47$ \\
\hline Microbial colonization & In the ventilator tubing. Group 1: 13 (59.1\%). Group 2: $16(80 \%) . p=0.14$ \\
\hline \multicolumn{2}{|r|}{ Authors: Zeitoun et al..$^{(18)}$} \\
\hline \multicolumn{2}{|c|}{ Groups studied: Group $1(n=24)$ : Open system; Group 2 ( $n=23):$ Closed system } \\
\hline Outcome & Result \\
\hline VAP & Group 1: 11 (45\%). Group 2: 7 (30.4\%). $p=0.278$ \\
\hline
\end{tabular}

(The Figure 3 continue in the next page...) 


\begin{tabular}{|c|c|}
\hline \multicolumn{2}{|r|}{ Authors: Darvas, Hawkins ${ }^{(19)}$} \\
\hline \multicolumn{2}{|c|}{$\begin{array}{r}\text { Groups studied: Group } 1(\mathrm{n}=53) \text { : Change of closed system every } 24 \text { hours } \\
\text { Group } 2(\mathrm{n}=48) \text { : Change of closed system every } 48 \text { hours }\end{array}$} \\
\hline Outcome & Result \\
\hline VAP & $\begin{array}{l}1^{\text {st }} \text { diagnostic criteria: no diagnosis of VAP in either Group } \\
\text { Modified criteria: Group 1: } 10(19 \%) \text {. Group 2: } 13(27 \%) . p=0.35 ; R R=1.5(C \mid 95 \%=0.6-3.7)\end{array}$ \\
\hline \multicolumn{2}{|r|}{ Authors: Quirke ${ }^{(20)}$} \\
\hline \multicolumn{2}{|c|}{$\begin{array}{r}\text { Groups studied: Group } 1(n=34): \text { Change of closed system every } 24 \text { hours } \\
\text { Group } 2(n=39): \text { Changer of closed system every } 48 \text { hours }\end{array}$} \\
\hline Outcome & Result \\
\hline Microbial colonization & $\begin{array}{l}\text { In endotracheal secretions on admission: Group 1: } 50 \% \text {; Group 2: } 66.66 \%(p=0.36) \text {. Lost data: Group 1: } \pm 11 \% \text {; Group } 2 \text { : } \\
\pm 2 \% \\
\text { In endotracheal secretions } 48 \text { hours post-admission: Group 1: } 41.17 \% \text {; Group 2: } 53.84 \%(p=0.19) \text {. Lost data: Group 1: } \\
\pm 15 \% \text {; Group 2: } \pm 16 \% \\
\text { From end of suction catheter: Group 1: } 50 \% \text {; Group 2: } 38.46 \% \text { ( } p=0.78) \text {. Lost data: Group 1: } \pm 20 \% \text {; Group 2: } \pm 40 \%\end{array}$ \\
\hline \multicolumn{2}{|r|}{ Authors: Kollef et al. ${ }^{(21)}$} \\
\hline \multicolumn{2}{|c|}{$\begin{array}{l}\text { Groups studied: Group } 1(n=263) \text { : Daily change of closed system suction catheter } \\
\text { Group } 2(n=258) \text { : Non-routine change of closed system suction catheter }\end{array}$} \\
\hline Outcome & Result \\
\hline VAP & Group 1: 39 (14.8\%). Group 2: 38 (14.7\%). $p=0.97 ; \mathrm{RR}=0.99(\mathrm{Cl} 95 \%=0.66-1.50)$ \\
\hline \multicolumn{2}{|r|}{ Authors: Ackerman, Mick ${ }^{(22)}$} \\
\hline \multicolumn{2}{|c|}{$\begin{array}{l}\text { Groups studied: Group } 1(n=14) \text { : Endotracheal suctioning with saline instillation } \\
\text { Group } 2(n=15) \text { : Endotracheal suctioning without saline instillation }\end{array}$} \\
\hline Outcome & Result \\
\hline CF & $\begin{array}{l}\text { A small increase occurred immediately after aspiration and the values returned close to the basal values (before } \\
\text { aspiration) after ten minutes. No significant difference between the Groups. } p \text { value not described. }\end{array}$ \\
\hline Systolic AP & $\begin{array}{l}\text { Increase in values immediately after aspiration in both Groups, returning to basal values at ten minutes after procedure. } \\
\text { No significant difference between the Groups. } p \text { value not described }\end{array}$ \\
\hline $\mathrm{SatO}_{2}$ & $\begin{array}{l}\text { Fall in values immediately after aspiration in both Groups. There was a statistical difference between the groups at } 4,5 \\
\text { and } 10 \mathrm{~min} \text { after aspiration }(p<0.05) \text {, with better results for Group } 2 .\end{array}$ \\
\hline \multicolumn{2}{|r|}{ Authors: Bostick, Wendelgass ${ }^{(23)}$} \\
\hline \multicolumn{2}{|c|}{$\begin{array}{l}\text { Groups studied: Group } 1(n=15) \text { : instillation of } 5 \mathrm{~mL} \text { of NS } \\
\qquad \begin{array}{l}\text { Group } 2(n=15) \text { : instillation of } 10 \mathrm{~mL} \text { of NS } \\
\text { Group } 3(n=15) \text { : endotracheal suctioning without instillation of NS }\end{array}\end{array}$} \\
\hline Outcome & Result \\
\hline $\mathrm{PaO}_{2}$ & No statistical difference between the Groups before or after aspiration \\
\hline $\begin{array}{l}\text { Quantity of secretion } \\
\text { aspirated }\end{array}$ & $\begin{array}{l}\text { After the treatment ( } n=45,15 \text { in each Group): there was no statistical difference between the Groups }(p>0.05) \\
\text { Measured before and after the treatment }(n=24,8 \text { in each Group): the weight of the secretion obtained after the aspiration } \\
\text { for Group } 1 \text { was significantly greater compared to the other Groups }(p<0.05) \text {. }\end{array}$ \\
\hline \multicolumn{2}{|r|}{ Authors: Caruso(24) } \\
\hline \multicolumn{2}{|c|}{$\begin{array}{r}\text { Groups studied: Group } 1(n=130) \text { : Endotracheal suctioning with saline instillation } \\
\text { Group } 2 \text { (132): Endotracheal suctioning without saline instillation }\end{array}$} \\
\hline Outcome & Result \\
\hline Atelectasis & $\begin{array}{l}\text { Pulmonary atelectasis/ } 100 \text { days of MV: Group } 1: 1.3 ; \text { Group } 2: 0.30 ; p=0.61 \\
\text { Lobar atelectasis/ } 100 \text { days of MV: Group 1: } 0.23 ; \text { Group } 2: 0.55 ; p=0.26 \\
\text { Segmental atelectasis/ } 100 \text { days of MV: Group 1: } 41.2 ; \text { Group } 2: 38.4 ; p=0.64\end{array}$ \\
\hline VAP & $\begin{array}{l}\text { Group 1: } 14(10.8 \%) \text {; Group 2: } 31(23.5 \%) ; p=0.008 \\
\text { Kaplan-Meier curve the proportion of patients who remained without VAP was greater in Group } 1 \text { ( } p=0.02 \text { log rank test). } \\
\text { The relative risk of reduction of VAP in Group } 1 \text { was } 54 \%(\mathrm{Cl} 95 \%=18 \%-74 \%)\end{array}$ \\
\hline
\end{tabular}

$\mathrm{CF}=$ Cardiac frequency $; \mathrm{AP}=$ Arterial pressure; $\mathrm{MAP}=$ Mean arterial pressure $; \mathrm{VAP}=$ Ventilator-associated pneumonia; $\mathrm{PP}=\mathrm{Pulse}$ pressure; $\mathrm{PaO}{ }_{2}=\mathrm{Arterial}$

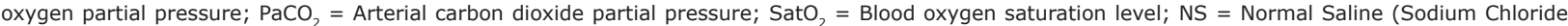
$0.9 \%$ solution); $\mathrm{MV}=$ Mechanical ventilation

Figure 3 - Distribution of the studies selected according to number of subjects per intervention Group, Outcome and Results. Ribeirão Preto, São Paulo, Brazil, 2011

In relation to the risk of bias in the studies selected (Figure 4), it may be observed that in $94.12 \%$ of the studies, the reliability of the results may be questioned, due both to uncertain levels of risk of bias and to high risk of bias. The uncertain level of risk of bias was visible in the following areas: generation of random sequence $(47.06 \%)$, allocation concealment (58.82\%), blinding of participants and care providers (41.18\%) and blinding of the evaluator of the outcome (52.94\%). The high risk of bias stood out in the following areas: blinding of the participants and care providers (47.06\%), blinding of the evaluator of the outcome $(17.65 \%)$ and other sources of bias (35.29\%).

Only one study ${ }^{(23)}$ reported a low risk of bias in all the 
areas analyzed; it's results, therefore, were considered highly reliable. In general, the areas in which a low risk of bias was predominant were: incomplete data about outcome (94.12\%), selective reporting (94.12\%) and other sources of bias (52.94\%).

\begin{tabular}{|c|c|c|c|c|c|c|c|}
\hline & 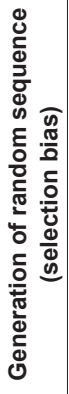 & 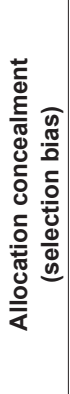 & 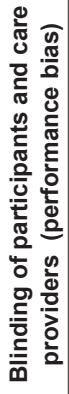 & 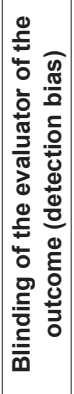 & 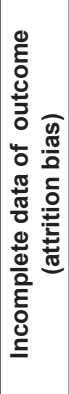 & 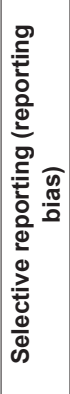 & 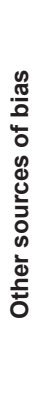 \\
\hline Celik, Elbas ${ }^{(8)}$ & $?$ & $?$ & - & - & + & - & - \\
\hline Leur et al..$^{(9)}$ & + & + & $?$ & $?$ & + & + & - \\
\hline Leur et al. ${ }^{(10)}$ & + & + & $?$ & $?$ & + & + & - \\
\hline Adams et al. ${ }^{(11)}$ & $?$ & $?$ & $?$ & $?$ & + & + & $?$ \\
\hline Combes et al. ${ }^{(12)}$ & $?$ & $?$ & - & + & + & + & + \\
\hline Johnson et al. ${ }^{(13)}$ & - & - & - & $?$ & $?$ & + & + \\
\hline Lorente et al. ${ }^{(14)}$ & $?$ & $?$ & $?$ & $?$ & + & + & + \\
\hline Lorente et al. ${ }^{(15)}$ & + & $?$ & $?$ & $?$ & + & + & + \\
\hline Rabitsch et al. ${ }^{(16)}$ & + & + & - & + & + & + & + \\
\hline Topeli et al. ${ }^{(17)}$ & $?$ & $?$ & - & $?$ & + & + & + \\
\hline Zeitoun et al. ${ }^{(18)}$ & - & - & $?$ & $?$ & + & + & $?$ \\
\hline Darvas, Hawkins ${ }^{(19)}$ & + & + & - & + & + & + & + \\
\hline Quirke ${ }^{(20)}$ & + & $?$ & $?$ & $?$ & + & + & - \\
\hline Kollef et al. ${ }^{(21)}$ & + & + & + & + & + & + & + \\
\hline Ackerman, Mick(22) & $?$ & $?$ & - & - & + & + & - \\
\hline Bostick, Wendelgass ${ }^{(23)}$ & $?$ & $?$ & - & - & + & + & - \\
\hline Caruso et al. ${ }^{(24)}$ & $?$ & $?$ & + & + & + & + & + \\
\hline
\end{tabular}

Figure 4 - Summary of the risk of bias according to study selected. Ribeirão Preto, São Paulo, Brazil, 2011

\section{Discussion}

In relation to the interventions studied and to the outcomes evaluated, it may be observed that on comparing research-based endotracheal suction with normal endotracheal suction, for the majority of outcomes evaluated, the results obtained were better for Groups which received interventions based on research. The study selected which covered this category of intervention ${ }^{(8)}$ shows various methodological limitations, as shown in the analysis of risk of bias. A low risk of bias was observed in only one of the areas analyzed. Due to this, the study results may be questioned.

Regarding minimally-invasive endotracheal suctioning( ${ }^{(9-10)}$, the results obtained evidence that this intervention is responsible for the lowest occurrence of adverse effects (hemodynamic alterations, $\mathrm{O}_{2}$ saturation, and presence of blood in the mucous), compared to normal endotracheal suctioning. This also applied to the memory of undergoing suctioning, which contributes to reducing the number of people who experience discomfort with the intervention. Despite the minimally-invasive suction producing the best results, a high number of protocol deviations were observed, in which patients allocated to the minimally-invasive suctioning group were, at some point, aspirated in the usual way ${ }^{(9)}$. This led to a high risk of bias in the area "other sources of bias" and suggests that, depending on the patient's condition, this form of aspiration may not be the most appropriate. The study in question ${ }^{(9)}$ reports that, probably, such an intervention would not be able to aspirate all the secretions present in the airways, causing its accumulation.

Regarding the studies which compared the open system of endotracheal suction with the closed system(11-18), it was observed that few presented a low risk of bias in relation to the allocation of subjects, allocation concealment and blinding. Prominent among the outcomes analyzed is the occurrence of ventilationassociated pneumonia (VAP). The criteria used for its diagnosis varied between the studies, however, there was no difference in the occurrence of VAP when the two systems of aspiration were compared.

In relation to cardiac frequency, arterial pressure and $\mathrm{O}_{2}$ saturation, the results found are in line with another review ${ }^{(25)}$, which included crossover studies, in addition to randomized controlled trials, with the best results occurring with the use of the closed system when compared to the open.

On analyzing the time interval for changing the closed suction system, the selected studies(19-21) $^{(10}$ presented a low risk of bias for the majority of their areas. Differences were not identified between the Groups where the systems were changed every 24 hours compared to every 48 hours, or with daily changing compared to non-routine changing, for any of the outcomes analyzed.

Regarding the instillation of normal saline before the endotracheal suction, compared to non-instillation, the selected studies ${ }^{(22-24)}$ present differences concerning how the suction was accomplished. Thus, different outcomes were observed, which made it impossible to undertake comparison between the studies. In relation to the results obtained for the outcomes analyzed, only oxygen saturation levels presented a result which was 
unfavorable to the saline instillation. Differences were not found between the Groups studied for cardiac frequency, arterial pressure, partial pressure of oxygen and atelectasis. The Group with saline instillation presented the best results regarding quantity of secretion aspirated. These results are questionable, however, as the quantity of normal saline instilled was not discounted from the measurement of the quantity of secretion collected. Further, in the case of this intervention, the study with the lowest risk of bias and the largest sample ${ }^{(24)}$ reported results favorable to saline instillation in the prevention of VAP.

Results of the analysis of these outcomes for the same intervention were found in other literature reviews ${ }^{(26-27)}$. One narrative review on the issue ${ }^{(26)}$ showed that despite including predominantly nonrandomized studies, and not evaluating the quality and risk of bias in said studies, the results obtained are similar to those found in the present review, in relation to cardiac frequency, arterial pressure and $\mathrm{O}_{2}$ saturation levels. Regarding the partial pressure of oxygen, results were found which contra-indicated the instillation of normal saline; differences were not found in relation to the quantity of secretion aspirated among the Groups studied. Further, evidence was found that the saline instillation increases the displacement of microorganisms from the endotracheal cannula to the lower airways, which would increase the risk of nosocomial pneumonia.

Another systematic review(27) on instillation of normal saline, which included other methodological designs and studies with pediatric and neonatal patients, found results similar to those of the present review for cardiac frequency, arterial pressure and partial pressure of oxygen, $\mathrm{O}_{2}$ saturation, and quantity of secretion aspirated. In relation to the occurrence of VAP, this review identified one study which did not find differences between the Groups analyzed.

It may be observed, therefore, that the evidence on instillation of normal saline remains contradictory. However, other studies ${ }^{(1-2,4)}$, which reviewed the practices of endotracheal suction, including studies with diverse methodological designs and populations (adult, pediatric, neonatal), submit recommendations which contra-indicate the instillation of normal saline.

From this review's findings, one may observe the lack of randomized controlled trials which cover the diverse aspects of endotracheal suction and outcomes. Due to this, guidelines put forward recommendations based in studies with lower levels of evidence, such as non-randomized, observational, quasi-experimental studies $^{(1)}$.

An ongoing controversy was also observed in the studies selected concerning the results of the outcomes analyzed for the interventions studied, due to there being few studies on specific interventions or outcomes, or due to differing results being found among the studies.

Another aspect observed was the lack of methodological information in the studies selected, compromising the analysis of risk of bias and, consequently, the evaluation of the results' reliability and validity. The importance can be seen, therefore, of publishing the RCT in line with the CONSORT recommendations (Consolidated Standards of Reporting Trials)(28), describing the methodological steps with enough detail for the studies' reliable comprehension, as well as making it possible to identify possible limitations.

Endotracheal suction is an intervention which requires specific knowledge about the patient's clinical condition, physio-pathological aspects, mechanical ventilation and respiratory therapy; therefore, studies for obtaining evidence upon which the practice is based are crucial. Based on the results obtained and the considerations made, it may be noted that although important evidence on endotracheal aspiration exists, this intervention still needs extensive investigation, principally through RCT.

\section{Conclusion}

Based on the results obtained from this systematic review, the following evidence on endotracheal suction was found:

- Research-based endotracheal suction produced the best results for mean arterial pressure, cardiac frequency, partial pressure of oxygen and partial pressure of carbon dioxide, when compared to usual aspiration;

- Minimally-invasive endotracheal suction, compared to routine endotracheal aspiration, results in fewer side effects (increase in systolic arterial pressure, increase in pulse pressure and drop in oxygen saturation levels) and less memories, in the patient, of having been suctioned; - The closed system of endotracheal suction had better results related to cardiac frequency, arterial pressure, cardiac rhythm, oxygen saturation levels and crosscontamination between the bronchial system and gastric juice, when compared to the open system. However, there was no difference between the two suction systems concerning the occurrence of VAP and microbial colonization of the endotracheal secretions and tubing of the ventilator; 
- The changing of the closed suction system every 48 hours or non-routinely, and its changing every 24 hours do not differ in terms of the occurrence of VAP. Neither was there any difference in microbial colonization of the endotracheal secretions and suction catheter, when the system was changed every 24 or 48 hours.

- Saline instillation and non-saline instillation do not differ in terms of cardiac frequency, arterial pressure, partial pressure of oxygen and the occurrence of atelectasis. Regarding the quantity of secretion aspirated, although results were identified which were favorable to the instillation of $05 \mathrm{~mL}$ of normal saline (compared to the instillation of $10 \mathrm{~mL}$ and non-saline instillation), conclusive evidence was not found about this outcome, due to the study's methodological limitations. In addition, the saline instillation was associated with lower occurrence of VAP, compared to non-saline instillation.

The methodological limitations and risks of bias found in the studies selected reduce the reliability of the evidence found, demonstrating the need for further studies.

\section{References}

1. American Association of Respiratory Care - AARC. AARC clinical practice guideline: endotracheal suctioning of mechanically ventilated patients with artificial airways 2010. Respir Care. 2010;55(6):758-64.

2. Pedersen CM, Rosendahl-Nielsen M, Hjermind J, Egerod I. Endotracheal suctioning of the adult intubated patient. What is the evidence? Intensive Crit Care Nurs. $2009 ; 25(1): 21-30$.

3. Ruiz VC, Oliveira LC, Borges F, Crocci AJ, Rugolo LMSS. Efeito da fisioterapia respiratória convencional e da manobra de aspiração na resistência do sistema respiratório e na saturação de $\mathrm{O} 2$ em pacientes submetidos à ventilação mecânica. Acta Fisiátrica. 1999;6(2):64-9.

4. Day T, Farnell S, Haynes S, Wainwright S, WilsonBarnett J. Tracheal suction: an exploration of nurses' knowledge and competence in acute and high dependency ward areas. J Adv Nurs. 2002;39(1):35-45.

5. Higgins JPT, Green S, editors. Cochrane Handbook for Systematic Reviews of Interventions Version 5.0.2 [atualizado setembro 2009]. [Internet]. The Cochrane Collaboration; 2009. [acesso 19 mar 2010]. Disponível em: www.cochrane-handbook.org.

6. Santos CMC, Pimenta CAM, Nobre MRC. The PICO strategy for the research question construction and evidence search. Rev. Latino-am. Enfermagem. 2007;15(3):508-11.
7. Higgins JPT, Green S, editors. Cochrane Handbook for Systematic Reviews of Interventions Version 5.1.0 [updated March 2011]. [Internet]. The Cochrane Collaboration; 2011. [acesso 18 abr 2011]. Disponível em: www.cochrane-handbook.org.

8. Celik SS, Elbas NO. The standard of suction for patients undergoing endotracheal intubation. Intensive Crit Care Nurs. 2000;16(3):191-8.

9. Van de Leur JP, Zwaveling JH, Loef BG, Van der Schans CP. Endotracheal suctioning versus minimally invasive airway suctioning in intubated patients: a prospective randomised controlled trial. Intensive Care Med. 2003;29(3):426-32.

10. Van de Leur JP, Zwaveling JH, Loef BG, Van der Schans CP. Patient recollection of airway suctioning in the ICU: Routine versus a minimally invasive procedure. Intensive Care Med. 2003;29(3):433-6.

11. Adams $\mathrm{DH}$, Hughes $\mathrm{M}$, Elliott TSJ. Microbial colonization of closed-system suction catheters used in liver transplant patients. Intensive Crit Care Nurs. 1997;13(2):72-6.

12. Combes $\mathrm{P}$, Fauvage B, Oleyer C. Nosocomial pneumonia in mechanically ventilated patients, a prospective randomised evaluation of the Stericath closed suctioning system. Intensive Care Med. 2000;26(7):878-82.

13. Johnson $\mathrm{KL}$, Kearney $\mathrm{PA}$, Johnson $\mathrm{SB}$, Niblett JB, MacMillan NL, McClain RE. Closed versus open endotracheal suctioning: costs and physiologic consequences. Crit Care Med. 1994;22(4):658-66.

14. Lorente $L$, Lecuona $M$, Jiménez $A$, Mora $M L$, Sierra A. Tracheal suction by closed system without daily change versus open system. Intensive Care Med. 2006;32(4):538-44.

15. Lorente L, Lecuona M, Martín MM, García C, Mora $\mathrm{ML}$, Sierra A. Ventilator-associated pneumonia using a closed versus an open tracheal suction system. Crit Care Med. 2005;33(1):115-9.

16. Rabitsch W, Köstler WJ, Fiebiger W. Closed suctioning system reduces cross-contamination between bronchial system and gastric juices. Anesth Analg. 2004;99(3):886-92.

17. Topeli A, Harmanci A, Cetinkaya Y, Akdeniz S, Unal $S$. Comparison of the effect of closed versus open endotracheal suction systems on the development of ventilator-associated pneumonia. J Hosp Infect. 2004;58(1):14-9.

18. Zeitoun SS, Barros ALBL, Diccini S. A prospective, randomized study of ventilator-associated pneumonia in 
patients using a closed vs. open suction system. J Clin Nurs. 2003;12(4):484-9.

19. Darvas JA, Hawkins LG. The closed tracheal suction catheter: 24 hour or 48 hour change? Aust Crit Care. 2003; 16(3)86-92.

20. Quirke, S. A comparative study of the incidence of nosocomial colonisation in patients with closed suction catheter changes at 24 versus 48 hours. Care of the Critically Ill. 1998;14(4):116-20.

21. Kollef MH, Prentice D, Shapiro SD, Fraser VJ, Silver P, Trovillion $\mathrm{E}$, et al. Mechanical ventilation with or without daily changes of in-line suction catheters. Am J Respir Crit Care Med. 1997;156(2 Pt 1):466-72.

22. Ackerman MH, Mick DJ. Instillation of normal saline before suctioning in patients with pulmonary infections: a prospective randomized controlled trial. Am J Crit Care. $1998 ; 7(4): 261-6$.

23. Bostick J, Wendelgass ST. Normal saline instillation as part of the suctioning procedure: effects on $\mathrm{PaO} 2$ and amount of secretions. Heart Lung. 1987;16(5):532-7.

24. Caruso P, Denari S, Ruiz SA, Demarzo SE, Deheinzelin D. Saline instillation before tracheal suctioning decreases the incidence of ventilator-associated pneumonia. Crit Care Med. 2009;37(1):32-8.

25. Jongerden IP, Rovers MM, Grypdonck MH, Bonten $M J$. Open and closed endotracheal suction systems in mechanically ventilated intensive care patients: a metaanalysis. Crit Care Med. 2007;35(1):260-70.

26. Celik SA, Kanan N. A current conflict: use of isotonic sodium chloride solution on endotracheal suctioning in critically ill patients. Dimens Crit Care Nurs. 2006;25(1):11-4.

27. Paratz JD, Stockton KA. Efficacy and safety of normal saline instillation: a systematic review. Physiotherapy. 2009;95(4):241-50.

28. Moher D, Hopewell S, Schulz KF, Montori V, Gøtzsche PC, Devereaux PJ, et al. CONSORT 2010 Explanation and Elaboration: updated guidelines for reporting parallel group randomised trials. J Clin Epidemiol. 2010;63(8):e1-37. [acesso 28 jun 2011]. Disponível em: http://www.sciencedirect.com/science/article/pii/ S0895435610001034. 